\title{
A Comparison between Corruption and Smuggling: Which One Is Worse?
}

\author{
Khandokar Istiak \\ Department of Economics and Finance, University of South Alabama, Mobile, AL, USA \\ Email:kistiak@southalabama.edu
}

How to cite this paper: Istiak, K. (2018) A Comparison between Corruption and Smuggling: Which One Is Worse? Theoretical Economics Letters, 8, 159-165. https://doi.org/10.4236/tel.2018.82011

Received: January 10, 2018

Accepted: February 4, 2018

Published: February 7, 2018

Copyright $\odot 2018$ by authors and Scientific Research Publishing Inc. This work is licensed under the Creative Commons Attribution International License (CC BY 4.0).

http://creativecommons.org/licenses/by/4.0/

\begin{abstract}
Corruption is a universal issue for almost all developing and underdeveloped countries. It is considered as one of the most important reasons that hamper economic growth. I follow a simple graphical approach to show the dreadful economic impact of corruption on the economy. I compare two evils, corruption with smuggling, and find that the welfare cost of corruption is higher than that of smuggling. I suggest merit-based recruitment of government officers and an independent judicial system to eradicate corruption from the economy.
\end{abstract}

\section{Keywords}

Corruption, Smuggling, Tariff, Welfare Cost

\section{Introduction}

Corruption is defined as the bribe-taking behavior in public offices (Dhillon et al. [1]). Generally, corruption reduces tax revenue as it compromises government ability and power to collect taxes (Kaufmann and Wei [2]). Mauro [3] and Bardhan [4] show how corruption creates a negative impact on growth and overall economic development of a country. Low wages of the government officers are often considered as a cause of corruption and the use of "efficiency" wages is proposed as a solution to corruption (see, for example, Amir and Burr [5]). There exists some recent literature that supports non-monetary incentives to minimize corruption. For example, Dhillon et al. [1] argue that maintaining a high status in the public sector as opposed to private sector will reduce corruption in the economy.

Whereas the existing studies follow a theoretical or empirical approach to explore the nature of corruption and the ways to eradicate it, I use a graphical ap- 
proach to show how bad the impact of corruption is on the economy. This approach has some advantages over the other approaches in two ways. First, the process is based on a simple supply-demand model and does not involve hefty econometric techniques. So, it is straightforward and easy to understand even to non-economists. Second, and most importantly, the corruption rate can be adjusted easily by this graphical approach. This provides a room to check the robustness of the baseline findings, as demonstrated in the last paragraph of Section 3.

In this paper, I only consider the corruption prevailing in the international trade sector. I define the amount of corruption equals to the bribe paid to the corrupted government officials to obtain the license of importing goods. I compare the adverse effects of corruption with those of smuggling, which is another curse for the economy. I examine whether there is a net welfare gain if a corrupted economy is turned into one that incurs smuggling. I find that there is a net gain if corruption is eradicated, but smuggling is introduced in the economy. So, I argue that the overall negative impact of corruption is larger than that of smuggling. I suggest that a strong, impartial, and independent judicial system can eliminate corruption from the economy.

The main contribution of this study is to demonstrate the alarming effects of import-based corruption by using a simple graphical approach. This is a theoretical paper and I do not use any empirical analysis in support of the findings. The theoretical findings of this paper can be confirmed by collecting data from an experimental lab setting. This can be treated as a scope of future research in this context.

The paper is organized in the following way. Section 2 provides a review of the past literature. Section 3 represents the graphical model to discuss the impact of smuggling and import based corruption in a hypothetical economy. The section also shows the net gain of switching from a corrupt economy to a smuggling prevailing economy. The final section provides the concluding remarks with the policy suggestions.

\section{The Literature Review}

Corruption is a widespread phenomenon in many developing countries. There are some excellent articles that discuss the nature of corruption in the economy. For example, Amir and Burr [5] explain the introduction of corruption in a Cournot industry with linear demand and costs. They argue that a firm may pay a bribe-maximizing official a fixed percentage of anticipated profit to have access to the industry. In this case, a monopoly may emerge that can create huge inefficiency in the economy. The importance of corruption from an economic viewpoint has also been noted in multiple research papers; for example, see Tullock [6], Rose-Ackerman [7], Jain [8], Aidt [9], Burguet and Chwe [10], among others.

Corruption disaffects the economy in a several number of channels. The ex- 
isting studies find that corruption slows down economic growth, total investment, and foreign direct investment (see, Mauro [3] and Wei [11]). Corruption increases the cost of production and drives the firms out of the official economy (Kaufmann [12]). The impact of corruption is also prevalent in the macroeconomy. For example, Tanzi and Davoodi [13] find that corruption reduces public sector budgets and hampers the productivity of a country's infrastructure. As corruption introduces huge social loss, it has attracted an increasing attention from the legislators, politicians and academic scholars. Many authors identify low wages of the government officials as the main reason for corruption (see, Amir and Burr [5], Becker and Stigler [14], Chand and Moene [15], among others). So, "efficiency wage" has been identified as a solution to prevent corruption, see Mahmood [16]. However, a large body of field experiments has found that monetary incentive may not be useful to eradicate corruption (see, Akerlof and Dickens [17] and Deci et al. [18]). So, the effectiveness of higher wages to remove corruption from the economy is still debated.

My research adds a new dimension to the literature because to show the negative effects of corruption I compare it with smuggling. I find that between the two evils, the corruption is the worse. I also show that the welfare cost of corruption is higher than that of smuggling. So, to the best of my knowledge, the technique of my research is unique in the literature.

\section{The Model}

In Figure 1, $D$ and $S$ indicate the domestic demand and supply curve of a product, respectively. The horizontal world price line $0 P_{1}$ is below the domestic equilibrium. In this case, the country will import that product from the rest of the world. When per unit tariff $P_{1} P_{3}$ is imposed, the price of the imported product would be $0 P_{3}$ in the domestic market. At this price, the import will be $C F$ and government revenue will be tariff times import or equal to the area of $C R S F$. The social loss from the tariff equals to the area of $C A R$ plus the area of FSH. They represent the production and consumption distortion cost of the domestic country, respectively.

If per-unit smuggling cost is less than the tariff, there is a possibility of smuggling. Smuggling cost can be any amount less than $P_{1} P_{3}$. I assume that the importers pay per unit smuggling cost of $P_{1} P_{2}$ to the border officials. The price of the imported product would be $0 P_{2}$ in the domestic market. At this price, the import will be $B G$, but the government does not earn any revenue.

Now I assume that the importers require a license to import goods and they need to pay per unit bribe of $P_{3} P_{4}$ to the corrupt administrative officers for obtaining the license. In Figure 1, I keep bribe $=$ smuggling cost or $P_{3} P_{4}=P_{1} P_{2}$ so that it is easy to compare their overall effects. If the bribe equals $P_{3} P_{4}$, the price of the imported product in the domestic market would be $0 P_{4}$. At this price import will be $T E$ and government revenue will be tariff times import or equal to area IMNJ. The corrupt officials here earn a total bribe of area TIJE. 


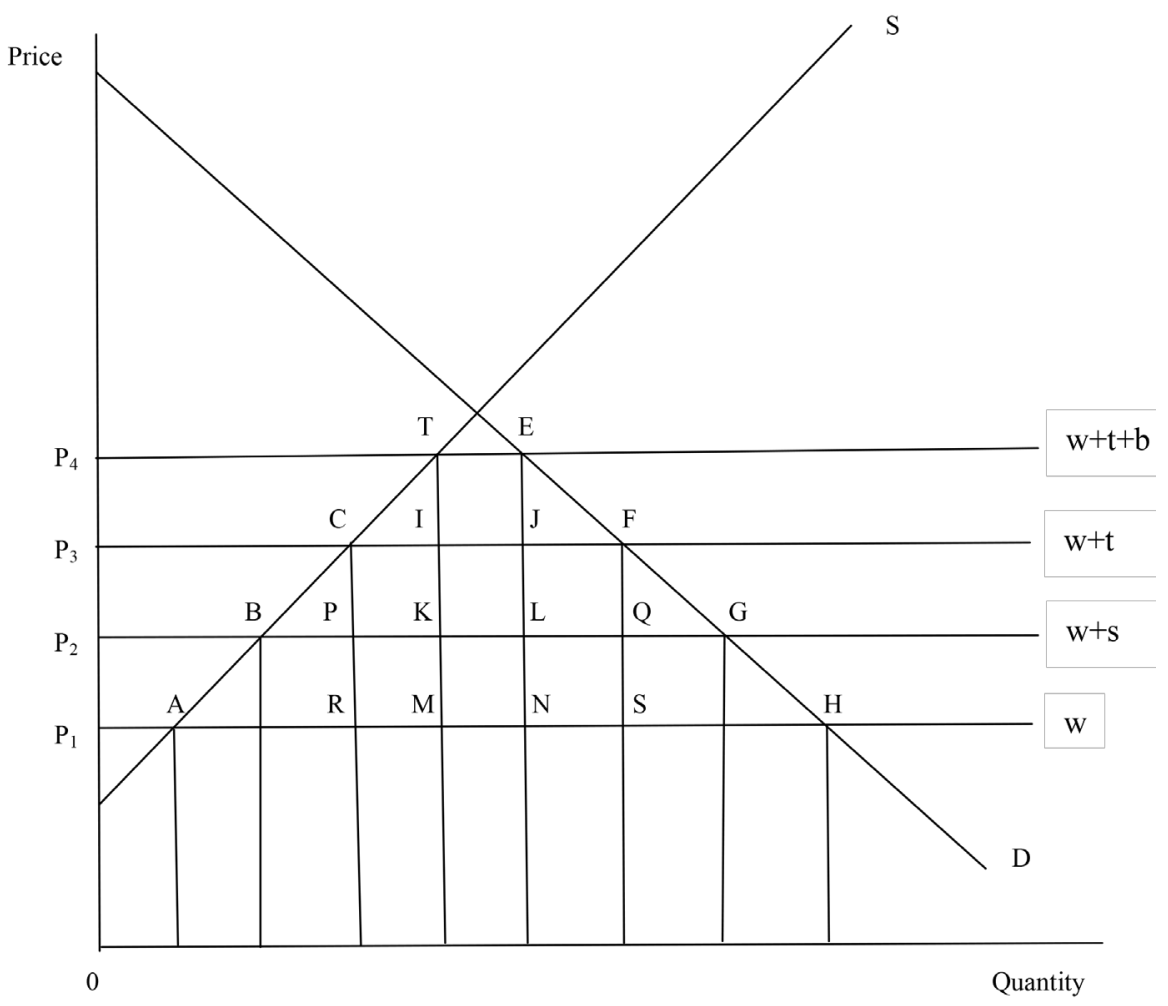

Figure 1. The economic impact and comparison of corruption vs. smuggling.

Both smuggling and corruption are harmful to the economy. To compare them I find the net gain of switching from corruption (when the price is $0 P_{4}$ ) to smuggling (when the price is $0 P_{2}$ ). If the net gain is positive, corruption is worse than smuggling. If the price declines from $0 P_{4}$ to $0 P_{2}$, the gain in consumer surplus equals area $P_{4} P_{2} G E$, the loss in producer surplus equals area $P_{4} P_{2} B T$, and the loss in government revenue equals area $I M N J$.

$$
\begin{aligned}
\text { Net gain } & =\operatorname{area}\left(P_{4} P_{2} G E-P_{4} P_{2} B T-I M N J\right) \\
& =\operatorname{area}(T B G E-I M N J) \\
& =\operatorname{area}(T B K+E L G+T I J E+I K L J)-\operatorname{area}(I K L J+K M N L) \\
& =\operatorname{area}(T B K+E L G)+\operatorname{area}(T I J E-K M N L)
\end{aligned}
$$

As smuggling cost $=$ bribe, area $T I J E=$ area $K M N L$. So, Equation (1) becomes

$$
\text { Net gain }=\text { area }(T B K+E L G)
$$

As the overall net gain of switching from corruption to smuggling is positive, the overall impact of corruption on the economy is worse than that of smuggling.

What is the intuition behind the result? According to the theory of international trade, if world price is $0 P_{1}$ and tariff amount is $P_{1} P_{3}$, the social cost equals the area $C A R$ plus the area $F S H$. These areas represent the production and consumption distortion cost, respectively. The society bears this loss because the government collects revenue (equals area $C R S F$ ) and some infant industries are protected by the tariff policy. In a corrupted economy, when a bribe is charged 
to obtain an import license, the importers pass the burden of bribe to the domestic consumers. As a result, the price of the imported product goes up and the total amount of import declines compared to a no corruption situation. Thus, the social cost of area $C A R$ and area $F S H$ increase to area $A T M$ and area $E N H$, respectively. Moreover, the government revenue now shrinks to area IMNJ only. So, both the government and the society suffer if corruption is introduced. On the other hand, under smuggling government does not get any revenue, but the price of the good is very low in the domestic market. The consumer surplus is so high in this case that the overall social cost of smuggling is lower than that of corruption.

I consider three cases to check the robustness of the finding. First, consider the case that the bribe rate is higher than the smuggling cost. In this case, the $0 P_{4}$ line shifts upward and the area of $(T B K+E L G)$ increases. The length of $T I$ and $E J$ increase but the length of $T E$ and $I J$ decrease. So, the area of TIJE remains roughly constant. Again, if the $0 P_{4}$ line shifts upward, the length of $K L$ and $M N$ decrease, but the length of $K M$ and $L N$ remain constant. So, the area of $K M N L$ declines. Thus, if $0 P_{4}$ line shifts upward, the area of (TIJE - KMNL) is still positive. So, overall the net gain of switching from corruption to smuggling in equation (1) is still positive. Second, consider the case that the bribe rate is lower than the smuggling cost. In this case, the $0 P_{4}$ line shifts downward and the area of $(T B K+E L G)$ decreases. The length of $T I$ and $E J$ decrease, but the length of $T E$ and $I J$ increase. So, the area of TIJE remains roughly constant. Again, if the $0 P_{4}$ line shifts downward, the length of $K L$ and $M N$ increase, but the length of $K M$ and $L N$ remain constant. So, the area of $K M N L$ increases. If the $0 P_{4}$ line does not shift downward by a large amount, the area of (TIJE - KMNL) is still positive. So, overall the net gain of switching from corruption to smuggling in Equation (1) is still positive. Third, consider the case that the country is reducing the tariff rate in the wake of globalization. In this case, the $0 P_{3}$ line shifts downward. Now the area of TIJE increases, but the area of $K M N L$ is unaffected. So, the area of $(T I J E-K M N L)$ goes up. In Equation (1), the area of $(T B K+E L G)$ will be unchanged, if the $O P_{3}$ line shifts downward. So, overall the net gain from switching from corruption to smuggling is still positive.

\section{Conclusions}

In this paper, I follow a graphical approach to examine whether there is a net welfare gain if a corrupted economy is turned into one that incurs smuggling. I find that if an economy switches from corruption to smuggling, the society achieves a net gain in welfare. So, the corruption based on paying bribes to obtain an import license is worse than smuggling. Corruption in the form of paying bribes leads to a biased distribution of income. Moreover, when corruption is introduced in fiscal sector, this leads to a low collection of revenue and thus hampers the development projects of the government. So, corruption hampers the overall growth prospects of the economy. 
I suggest a free market economy with less government regulation. This will reduce the scope to pay bribes to the corrupt officials. Moreover, the recruitment of government officers must be strictly merit-based. Proper punishment must be specified if any case of nepotism and rent-seeking activities are found in case of recruitment. Also, to combat corruption, a well-motivated salary compensated with domestic inflation must be proposed to the civil servants. Above all, a strong, impartial and independent judicial system, the freedom of the press, and democracy are important to prevent corruption from the country.

\section{Acknowledgements}

I am indebted to an anonymous reviewer whose valuable insights and comments have greatly improved this paper.

\section{References}

[1] Dhillon, A., Nicolo, A. and Xu, F. (2017) Corruption, Intrinsic Motivation and the Love of Praise. Journal of Public Economic Theory, 19, 1077-1098. https://doi.org/10.1111/jpet.12278

[2] Kaufmann, D. and Wei, S. (1999) Does “Grease Money" Speed Up the Wheels of Commerce? NBER Working Paper No. w7093. https://ssrn.com/abstract=162974

[3] Mauro, P. (1995) Corruption and Growth. Quarterly Journal of Economics, 110, 681-712. https://doi.org/10.2307/2946696

[4] Bardhan, P. (1997) Corruption and Development: A Review of Issues. Journal of Economic Literature, 35, 1320-1346.

[5] Amir, R. and Burr, C. (2015) Corruption and Socially Optimal Entry. Journal of Public Economics, 123, 30-41. https://doi.org/10.1016/j.jpubeco.2014.12.012

[6] Tullock, G. (1967) The Welfare Cost of Tariffs, Monopoly and Theft. Economic Inquiry, 5, 224-232. https://doi.org/10.1111/j.1465-7295.1967.tb01923.x

[7] Rose-Ackerman, S. (1978) Corruption: A Study in Political Economy. Academic Press, New York.

[8] Jain, A.K. (2001) Corruption: A Review. Journal of Economic Surveys, 15, 71-121. https://doi.org/10.1111/1467-6419.00133

[9] Aidt, T. (2003) Economic Analysis of Corruption: A Survey. The Economic Journal, 115, 632-652. https://doi.org/10.1046/j.0013-0133.2003.00171.x

[10] Burguet, R. and Chwe, Y.K. (2004) Competitive Procurement with Corruption. The RAND Journal of Economics, 35, 50-68. https://doi.org/10.2307/1593729

[11] Wei, S.J. (2000) How Taxing Is Corruption on International Investors? The Review of Economics and Statistics, 82, 1-11. https://doi.org/10.1162/003465300558533

[12] Kaufmann, D. (1997) Corruption: The Facts. Foreign Policy, 107, 114-131. https://doi.org/10.2307/1149337

[13] Tanzi, V. and Davoodi, H. (1997) Corruption, Public Investment, and Growth. IMF Working Paper No. 97/139. https://www.imf.org/external/pubs/ft/wp/wp97139.pdf

[14] Becker, G. and Stigler, G. (1974) Law Enforcement, Malfeasance, and Compensation of Enforcers. Journal of Legal Studies, 3, 1-18. https://doi.org/10.1086/467507

[15] Chand, S. and Moene, K. (1999) Controlling Fiscal Corruption. World Development, 27, 1129-1140. https://doi.org/10.1016/S0305-750X(99)00050-9 
[16] Mahmood, M. (2005) Corruption in Civil Administration: Causes and Cures. $\mathrm{Hu}$ manomics, 21, 62-84. https://doi.org/10.1108/eb018905

[17] Akerlof, G. and Dickens, W. (1982) The Economic Consequences of Cognitive Dissonance. American Economic Review, 72, 307-319.

[18] Deci, E., Koestner, R. and Ryan, R. (1999) A Meta-Analytic Review of Experiments Examining the Effects of Extrinsic Rewards on Intrinsic Motivation. Psychological Bulletin, 125, 627-668. https://doi.org/10.1037/0033-2909.125.6.627 